\title{
LOCAL PEOPLE'S PERCEPTIONS AND ATTITUDES TOWARDS A GREEN CITY: CASE STUDY OF PERUNGUDI, CHENNAI, INDIA
}

\author{
SHARMILA JAGADISAN \\ VIT University, India
}

\begin{abstract}
One of the more promising Sustainable Development Goals is to promote prosperity in protecting the planet by using the "green city" as one of the catalysts. To raise environmental awareness, World Environment Day has been celebrated on 5 June since 1974, and while the concept of a "green city" has started to gain momentum in India, high population density and land scarcity has forced people to settle near ecologically sensitive areas within conventional development models, which has led to the rapid deterioration of resources. The crucial starting point for this paper is to find out whether the knowledge of the "green city" has had deeper penetration to all sectors of the population. The main objective is to evaluate the extent to which individuals and local governance are involved in the "green city" movement. Our research investigates whether we have responsive and inclusive government institutions with the capacity to deliver services efficiently and equitably. The author has taken Perungudi, which is one of the fastest growing suburbs in Chennai city due to a rapidly growing IT industry, as a case study. This research first divides the Perungudi area into two districts based on the socio-economic status and then investigates local people's knowledge and perception of the "green city" based on the following tools: (i) a household survey; (ii) secondary reports; and (iii) a transect walk. The results underline how much work lies ahead for "green city" advocates: revealing the gaps in our knowledge about public attitudes towards the "green city" concept.

Key words: SDG's, green city, awareness, socio-economic, development, deterioration.
\end{abstract}

\section{INTRODUCTION}

The concept of Green city has gained widespread attention in the recent years and has been discussed at large due to destruction of eco-system and extensive habitat loss by the anthropogenic activity on the environment. To raise environmental awareness June $5^{\text {th }}$ has been scheduled to mark as the World Environment Day. Historically the concern for environmental conservation and the deep ecological consciousness pervaded in the entire Indian civilization which can be traced back to the ancient Vedic period, but it was lost somewhere due to the drastic changes in the social, economic and cultural factors. In recent decades India's rapid urbanisation with burgeoning population has depleted green cover and increased vulnerability of ecologically sensitive areas. The crucial starting point for this paper is to find out whether the knowledge of the "green city" has had deeper penetration to all sectors of the population. The main objective is to evaluate the extent to which individuals and local governance are involved in the "green city" movement. This research investigates whether we have responsive and inclusive government institutions with the capacity to deliver services efficiently and equitably. As a case study the author has taken Perungudi, which is one of the fastest growing suburbs in Chennai city, Tamil Nadu, India due to rapidly growing IT industry.

\subsection{Concept of Green City at the national and regional level in India}

In the past two decades rapid and unplanned development poses significant quality of life challenges such high level of pollution (air, water and noise), loss of bio-diversity, lack of 
green spaces and vegetation, high impermeability rates in cities which intensifies the formation of urban heat, inefficient household waste management etc. imposing city dwellers to experience more stressful life style. City authorities have prime responsibility to keep balance between urban development and sustainability for the present and future generations. These green spaces and green belts are considered to be the lungs of the cities as they act as a sink for green-house gases. According to Razia [1] residents get the social benefits of urban green space in terms of recreational opportunity, mental well-being, aesthetic enjoyment, and social bonding. Thus, urban green space is playing a vital role on social issues in the mega cities. Planning for development is a systematic envisioning process which requires a sound assessment of the ground issues and providing concrete options for actions towards sustainable development. The concept of Green city or "eco-city" means a way to increase the sustainability of urbanized areas. It is a concept of urban planning relying on the services such as understanding the dynamics of urban ecosystem and the role of biodiversity, minimizing resource and energy consumption, and taking advantage of the ecosystem services of the blue-green natural components.

Taking into account the existing scenario the Ministry of urban development in India developed a framework called URDPFI (Urban and Regional development Planning Formulation and Implementation) [2] which is a comprehensive guideline for regional and urban planning process. This guideline has been divided into 2 volumes. The Volume-I incorporates the planning process, contents of the plans resource mobilisation for plan implementation including land and finance as the primary resources for sustainable development, institutional reforms particularly at State level etc. whereas the second volume deals with the legal requirements for industrial development, State level planning framework and other National level requirements for heritage and environment conservation with the relevant Acts/Law/Notifications etc. Fig. 1 illustrates the indicators of Green city as per URDPFI guidelines. With respect to the regional level one of the spatial strategies that have been put forward by CMDA for 2026 Master Plan regarding natural environment is given below:

12.14 As a part of the non-urban use zone natural environment to be protected from urbanization such as forests, streams and other water bodies including the numerous tanks and eries (lakes) and swamps and other lands unsuitable for urban development are to be prevented for urban development such as water recharging and recovery areas have been zoned specifically for these purposes.

\section{CASE STUDY: PERUNGUDI}

Perungudi is one of the fastest growing neighbourhoods in Chennai city which is $10 \mathrm{~km}$ situated south of Adyar. This locality is a part of the eminent IT corridor and is been bordered by (OMR) Old Mahabalipuram road which is an expressway and it houses more than 60 top notch IT companies and several small-scale industries, and it is being increasingly preferred as a residential place for software engineers. As per 2011 census [4] the population of Perungudi is 43,111 a suburb which is been inhabited by an equal mix of new migrants and descendants of some early clans who migrated to the area approximately 300 years ago. Perungudi has a lake which was spread over 50 acre water body, once a major source for irrigation. Currently it caters to the ever-growing water demand of the domestic needs and it helps in recharging ground water. Fig. 2 shows the location of Perungudi map. 


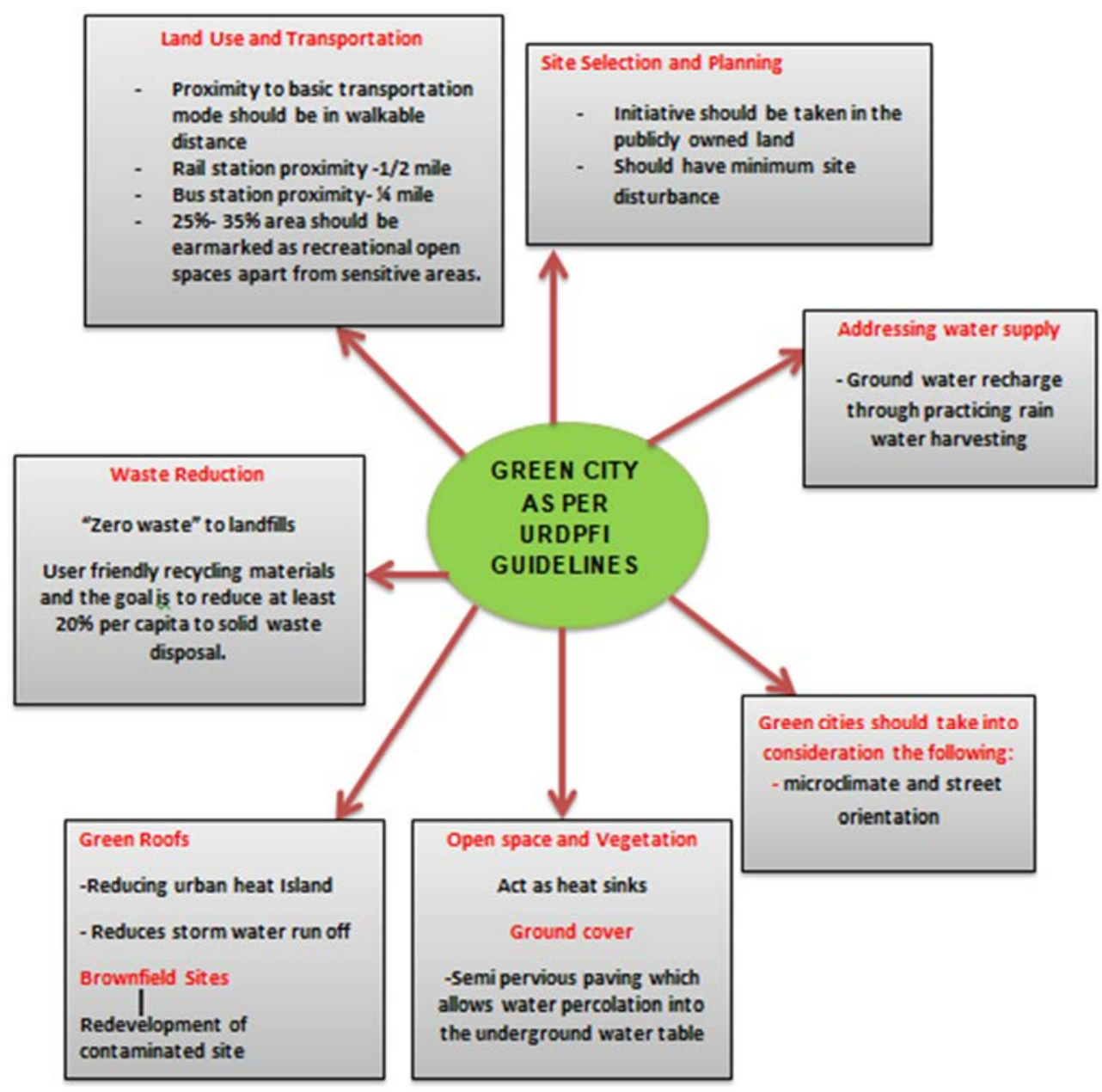

Figure 1: Indicators of a Green city as per the URDPFI guidelines [3].

\subsection{Purpose of the paper}

The selected area of Perungudi was marked with a boundary with longest radius of $1.54 \mathrm{~km}$ towards South-west from Perungudi lake and with shortest radius of $1.0 \mathrm{~km}$ towards East from Perungudi lake ward number $-184-186$ and the extent of the area is 4.3 sq.km. This research first divides the Perungudi area into two districts based on the socio-economic status, then investigates local people's knowledge and perception of the "green city" based on the following tools (i) a household survey; (ii) secondary reports and (iii) a transect walk. The results underline how much work lies ahead for "green city" advocates: revealing the gaps in our knowledge about public attitudes towards the "green city" concept.

\section{QUESTIONNAIRE SURVEY AND DATA ANALYSIS}

The survey was done twice in both the districts by the author. A questionnaire survey was conducted after one-to-one pilot study which was initially done in 2018 with 30 local people 


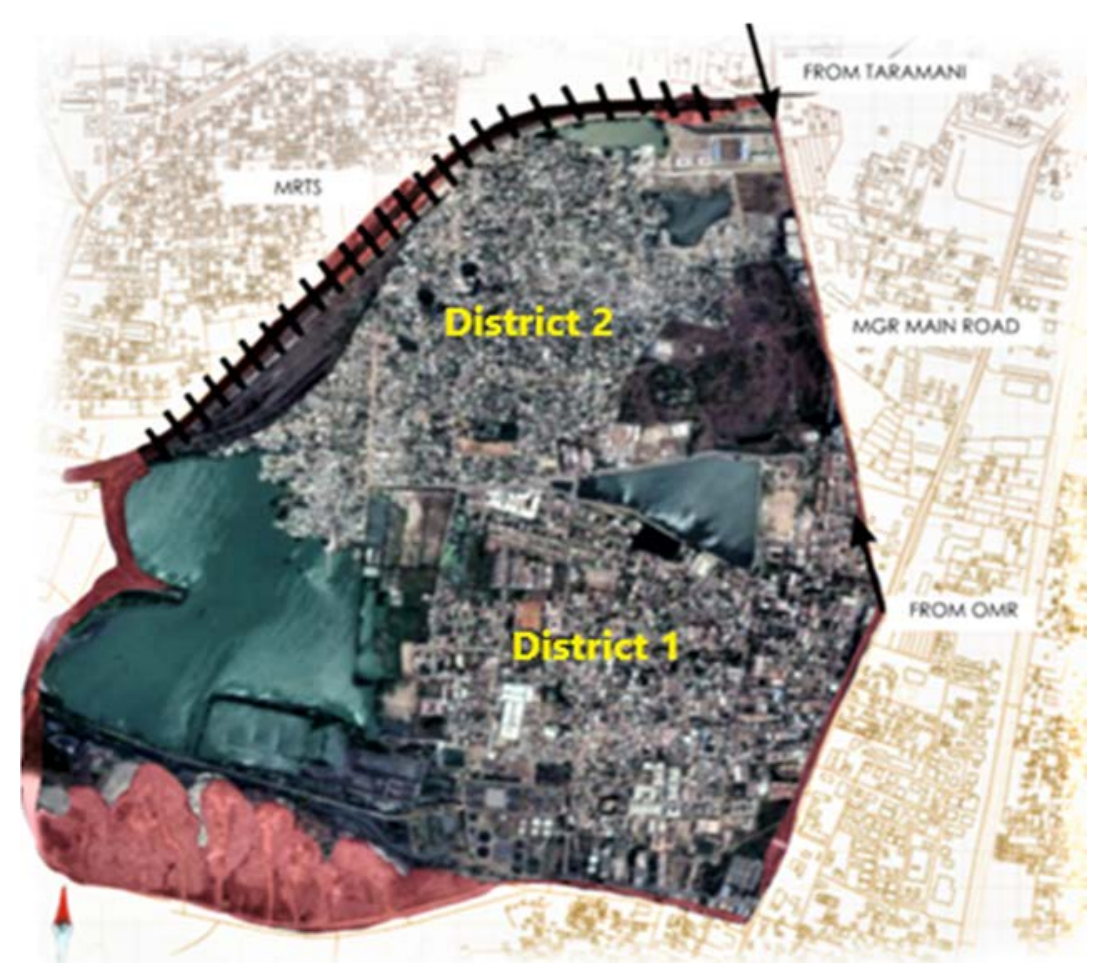

Figure 2: Map of Perungudi in Chennai [5].

(15 from each district) in order to identify the level of understanding on the green city concepts such as waste management, environmental awareness, main uses of green space, distance to the parks, water quality, transportation and types of vegetation. This helped in further refining the questionnaire so that it ensured that the participants understood the questions uniformly and encourage the respondent to provide accurate, unbiased and complete information. After 6 months the main survey was subsequently conducted with a structured questionnaire (English and Tamil). The cluster sampling method was adopted with an overall target of 150 respondents (survey was done by the author and was helped by 2 Asst. Architects) (75 respondents from each district) and the interviews were conducted face to face, on weekends, weekday evenings, and other times when visitors were in large numbers, thereby sampling across the representation available of gender, education, and professional background. The response formats were either open, in ranking scale, or closed (dichotomous, multiple choices, Likert scale). Descriptive statistics with weighted average score to find out rank of the most expected tools for enhancing green space. Fig. 3 shows the percentage of respondents who participated in the survey from District 1 and District 2 along with their age limits.

The questionnaire survey was mainly framed with different indicators to analyse and understand the local people views on Green cities. Respondents feedback has been calculated with Weighted Average Score (WAS) and rank (Rk) with their age limits (20-60 years). Table 1 illustrates the local people's perception and understanding on the indicators of Green cities at Perungudi and Fig. 4 shows the comparison of the weighted average score between District 1 and District 2. 
District 1

- Male $=$ Female

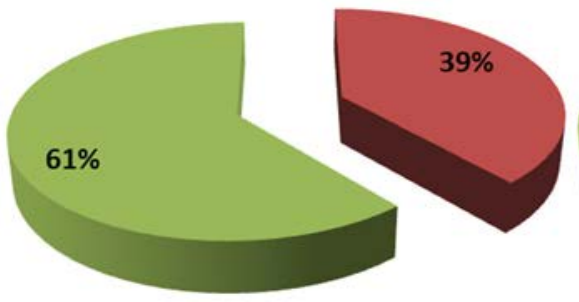

District 2

Male Female
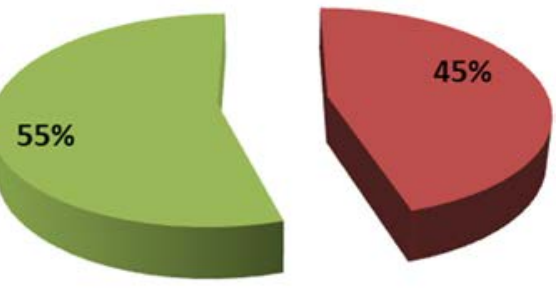

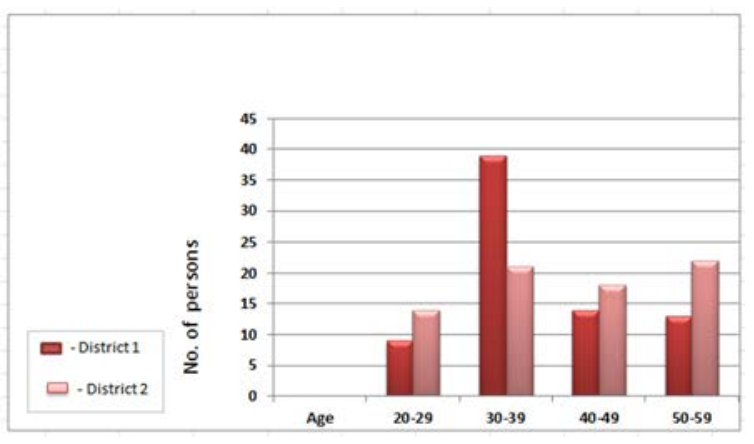

Figure 3: Percentage of respondents (male and female) along with their age limits.

Table 1: Local people's perception and understanding on the indicators of Green cities.

\begin{tabular}{|c|c|c|c|c|c|c|c|c|c|c|c|}
\hline & & \multicolumn{5}{|c|}{ DISTRICT ONE } & \multicolumn{5}{|c|}{ DISTRICT TWO } \\
\hline S.No. & $\begin{array}{l}\text { Local people's perception } \\
\text { and understanding on Green } \\
\text { cities indicators }\end{array}$ & Scale & $\mathrm{F}_{\mathrm{r}}$ & $\%$ & WAS & $\mathrm{R}_{\mathrm{K}}$ & Scale & $F_{r}$ & $\%$ & WAS & $\mathrm{R}_{\mathrm{K}}$ \\
\hline 1. & $\begin{array}{l}\text { More no. of trees and green } \\
\text { cover }\end{array}$ & NAI & 0 & 0 & \multirow{6}{*}{4.764} & \multirow{6}{*}{3} & NAI & 0 & 0 & \multirow{6}{*}{4.52} & \multirow{6}{*}{1} \\
\hline & & UI & 0 & 0 & & & UI & 0 & 0 & & \\
\hline & & LI & 2 & 3.0 & & & LI & 1 & 1.33 & & \\
\hline & & I & 14 & 18.66 & & & I & 33 & 44 & & \\
\hline & & MI & 59 & 78.66 & & & MI & 41 & 54.6 & & \\
\hline & & Total & 75 & 100.00 & & & Total & 75 & 100.0 & & \\
\hline \multirow[t]{6}{*}{2.} & Open space and parks & NAI & 0 & 0 & \multirow{6}{*}{5.00} & & NAI & 0 & 0 & \multirow{6}{*}{4.28} & \multirow{6}{*}{2} \\
\hline & & UI & 0 & 0 & & \multirow{5}{*}{1} & UI & \begin{tabular}{|l|l|}
0 \\
\end{tabular} & 0 & & \\
\hline & & LI & 0 & 0 & & & LI & 6 & 8 & & \\
\hline & & $\mathrm{I}$ & 1 & 1.33 & & & $\mathrm{I}$ & 42 & 56 & & \\
\hline & & MI & 74 & 98.66 & & & MI & 27 & 36 & & \\
\hline & & Total & 75 & 100.00 & & & Total & 75 & 100.00 & & \\
\hline \multirow[t]{6}{*}{3.} & Ground water recharge & NAI & 0 & 0 & \multirow{6}{*}{4.68} & \multirow{6}{*}{4} & NAI & 0 & 0 & \multirow{6}{*}{4.17} & \multirow{6}{*}{4} \\
\hline & & UI & 0 & 0 & & & UI & 0 & 0 & & \\
\hline & & LI & 3 & 4 & & & LI & 12 & 16 & & \\
\hline & & I & 18 & 24 & & & I & 38 & 50.66 & & \\
\hline & & MI & 54 & 72 & & & MI & 25 & 33.33 & & \\
\hline & & Total & 75 & 100 & & & Total & 75 & 100 & & \\
\hline
\end{tabular}


Table 1: Continued.

\begin{tabular}{|c|c|c|c|c|c|c|c|c|c|c|c|}
\hline & & \multicolumn{5}{|c|}{ DISTRICT ONE } & \multicolumn{5}{|c|}{ DISTRICT TWO } \\
\hline S.No. & $\begin{array}{l}\text { Local people's perception } \\
\text { and understanding on Green } \\
\text { cities indicators }\end{array}$ & Scale & $\mathrm{F}_{\mathrm{r}}$ & $\%$ & WAS & $\mathrm{R}_{\mathrm{K}}$ & Scale & $\mathrm{F}_{\mathrm{r}}$ & $\%$ & WAS & $\mathrm{R}_{\mathrm{K}}$ \\
\hline 4. & Reduced air pollution & NAI & 0 & 0 & \multirow{7}{*}{4.78} & \multirow{7}{*}{2} & NAI & 0 & 0 & \multirow{7}{*}{4.25} & \multirow{7}{*}{3} \\
\hline & & UI & 0 & 0 & & & $\mathrm{UI}$ & 0 & 0 & & \\
\hline & & & & & & & & & & & \\
\hline & & LI & 0 & 0 & & & LI & 12 & 16 & & \\
\hline & & I & 16 & 21.33 & & & I & 32 & 42.66 & & \\
\hline & & MI & 59 & 78.66 & & & MI & 31 & 41.33 & & \\
\hline & & Total & 75 & 100.00 & & & Total & 75 & 100.00 & & \\
\hline \multirow[t]{6}{*}{5.} & $\begin{array}{l}\text { Proximity to public transport } \\
+ \text { good transport }\end{array}$ & NAI & 31 & 41.33 & \multirow{6}{*}{2.03} & \multirow{6}{*}{8} & NAI & 43 & 57.33 & \multirow{6}{*}{1.63} & \multirow{6}{*}{10} \\
\hline & & UI & 22 & 29.33 & & & $\mathrm{UI}$ & 18 & 24 & & \\
\hline & & LI & 12 & 16 & & & LI & 12 & 16 & & \\
\hline & & I & 8 & 10.66 & & & I & 2 & 2.6 & & \\
\hline & & MI & 2 & 2.66 & & & MI & 0 & 0 & & \\
\hline & & Total & 75 & 100.00 & & & Total & 75 & 100.00 & & \\
\hline \multirow[t]{6}{*}{6.} & $\begin{array}{l}\text { Decrease number in flora } \\
\text { and fauna }\end{array}$ & NAI & 29 & 38.66 & \multirow{6}{*}{2.13} & \multirow{6}{*}{7} & NAI & 38 & 50.66 & \multirow{6}{*}{1.7} & \multirow{6}{*}{8} \\
\hline & & $\mathrm{UI}$ & 18 & 24 & & & $\mathrm{UI}$ & 22 & 29.33 & & \\
\hline & & LI & 20 & 26.66 & & & LI & 15 & 20 & & \\
\hline & & I & 5 & 6.66 & & & I & 0 & 0 & & \\
\hline & & MI & 3 & 4 & & & MI & 0 & 0 & & \\
\hline & & Total & 75 & 100.00 & & & Total & 75 & 100.00 & & \\
\hline \multirow[t]{6}{*}{7.} & Reduction in surface run-off & NAI & 7 & 9.33 & \multirow{6}{*}{3.71} & \multirow{6}{*}{6} & NAI & 17 & 22.66 & \multirow{6}{*}{3.03} & \multirow{6}{*}{6} \\
\hline & & $\mathrm{UI}$ & 8 & 10.66 & & & $\mathrm{UI}$ & 18 & 24 & & \\
\hline & & LI & 6 & 8 & & & LI & 4 & 5.33 & & \\
\hline & & $\mathrm{I}$ & 32 & 42.66 & & & $\mathrm{I}$ & 17 & 22.66 & & \\
\hline & & MI & 22 & 2933 & & & MI & 19 & 2533 & & \\
\hline & & Total & 75 & 100.00 & & & Total & 75 & 100.00 & & \\
\hline 8. & $\begin{array}{l}\text { Recycling waste + zero } \\
\text { waste to landfills }\end{array}$ & NAI & 29 & 38.66 & & & NAI & 35 & 46.66 & & \\
\hline & & $\mathrm{UI}$ & 27 & 36 & & & $\mathrm{UI}$ & 18 & 24 & & \\
\hline & & LI & 12 & 16 & 2.02 & 9 & LI & 22 & 29.33 & 1.82 & 7 \\
\hline & & $\mathrm{I}$ & 2 & 2.66 & & & $\mathrm{I}$ & 0 & 0 & & \\
\hline & & MI & 5 & 6.66 & & & MI & 0 & 0 & & \\
\hline & & & 75 & 100.00 & & & Total & 75 & 100.00 & & \\
\hline 9. & Reduced air temperature & NAI & 18 & 24 & & & NAI & 28 & 37.33 & & \\
\hline & & UI & 0 & 0 & & & UI & 5 & 6.66 & & \\
\hline & & LI & 0 & 0 & 372 & 5 & LI & 0 & 0 & 306 & 5 \\
\hline & & I & 24 & 32 & 3.12 & 5 & I & 18 & 24 & 3.06 & 5 \\
\hline & & MI & 33 & 44 & & & MI & 24 & 32 & & \\
\hline & & Total & 75 & 100 & & & Total & 75 & 100.00 & & \\
\hline 10. & $\begin{array}{l}\text { Setbacks in buildings with } \\
\text { green covers }\end{array}$ & NAI & 32 & 42.66 & & & NAI & 42 & 56 & & \\
\hline & & $\mathrm{UI}$ & 27 & 36 & & & $\mathrm{UI}$ & 15 & 20 & & \\
\hline & & LI & 7 & 9.33 & 1.97 & 10 & LI & 18 & 24 & 1.68 & 9 \\
\hline & & I & 4 & 5.33 & & & I & 0 & 0 & & \\
\hline & & MI & 5 & 6.66 & & & $\mathrm{MI}$ & 0 & 0 & & \\
\hline & & Total & 75 & 100.00 & & & Total & 75 & 100.00 & & \\
\hline
\end{tabular}




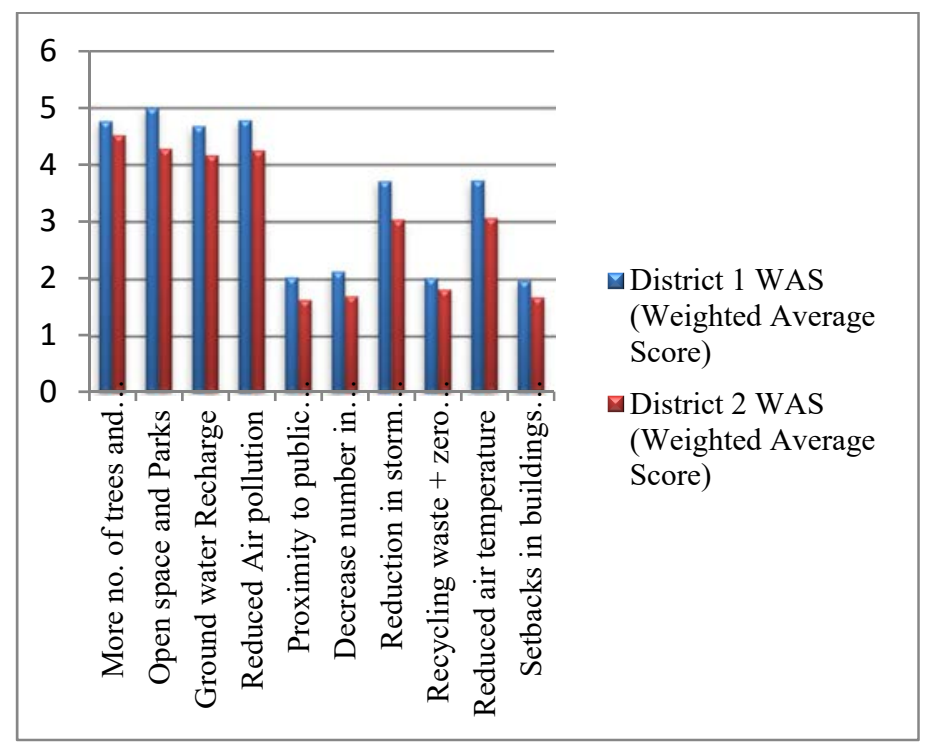

Figure 4: Comparison of the weighted average score between District 1 and District 2.

\section{RESPONDENTS FEEDBACK AND EXISTING CONDITIONS}

\subsection{Indicators 1 and 2: Number of tress and green cover and open space and parks}

Feedback: According to the survey it is clear that people from both the districts felt that a greater number of trees, open space and parks are the indicators relevant for green cities with weighted average score of 4.764 and 5.00 respectively in District 1 and 4.674 and 4.8 in District 2.

Existing Condition: As per the observation there are 4 parks within the study area. As shown in Fig. 5 two parks (CBI Colony park (1) and Thirumalai nagar park (2)) are not accessible visually and physically. The authorities have not taken any initiative to make the parks active and put into use. The major reason for visiting parks infrequently by the respondents was of "recreational facilities and green covers" $(58 \%)$, followed by "lack of legibility" (24\%) and absence of a clear pedestrian linkage and an integrative public transport $(18 \%)$. And also the distribution of green covers is not even. From the overall observation in both the districts the author concludes that the respondents of Perungudi are not aware of various benefits of trees, other than its shade value.

\subsection{Indicator 3: Ground water recharge}

With the weighted average score of 4.68 from District 1 it is very clear that people are aware that augmentation of water and rainwater harvesting are the indicators of green cities. On the contrary from District 2, 67\% of the population believes ground water recharge is important for their area to be green. But the remaining $33 \%$ of the people blame on their local government for water shortage and they assume ground water to be from the supply-side perspective that lacks an understanding of what the resource is, and what we need to do to ensure better use of it. 


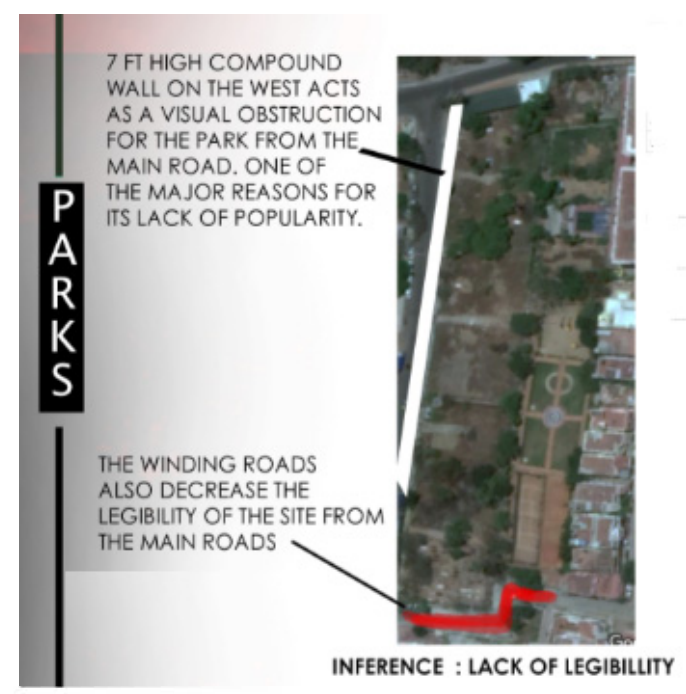

\section{INFERENCE : LACK OF RECREATIONAL SPACES FOR KIDS}

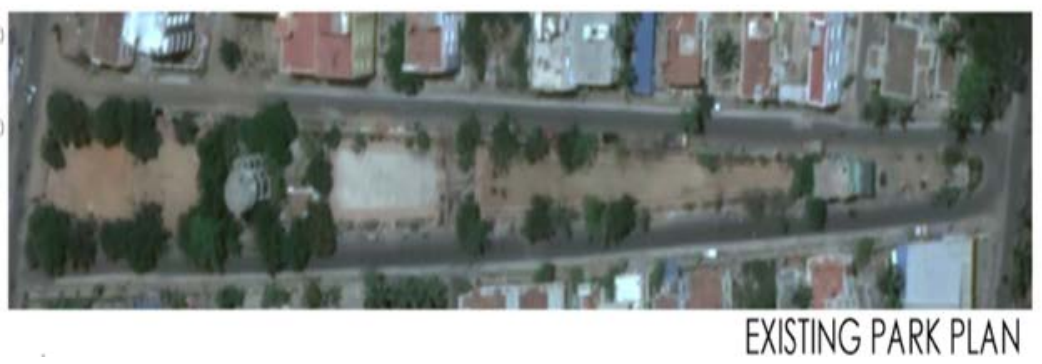

Figure 5: CBI park and Thirumalai Nagar park where lack of recreational facilities and green covers (park 2) followed by lack of legibility in park 1 [6].

Existing condition: In District 1 people residing in the vicinity of the Perungudi lake (Fig. 6) undertook a clean-up of the lake (with the help of association called PLANET who are volunteers from District 1) and its bunds and they also celebrate lake festival every year to showcase the significance of their lake. The group felt the need for networking with the objective of ensuring the lakes protection and environmental health which clearly indicates that they show commitment, knowledge and awareness in relation to natural resources and the environment that surrounds them. But on the contrary people from District 2 who are unauthorized occupiers uses the lake as their washroom.

\subsection{Indicator 4: Reduced air pollution}

People in both the districts felt that reduction in air pollution is a direct implication to green cities. It is also observed that the levels of plantation in both the districts are not keeping pace with the urban development. From the interaction with the respondents in District 1 it has been found that, missing sense of ownership on the street vegetation and trees among the community is one of the prime reasons for declining tree cover. 


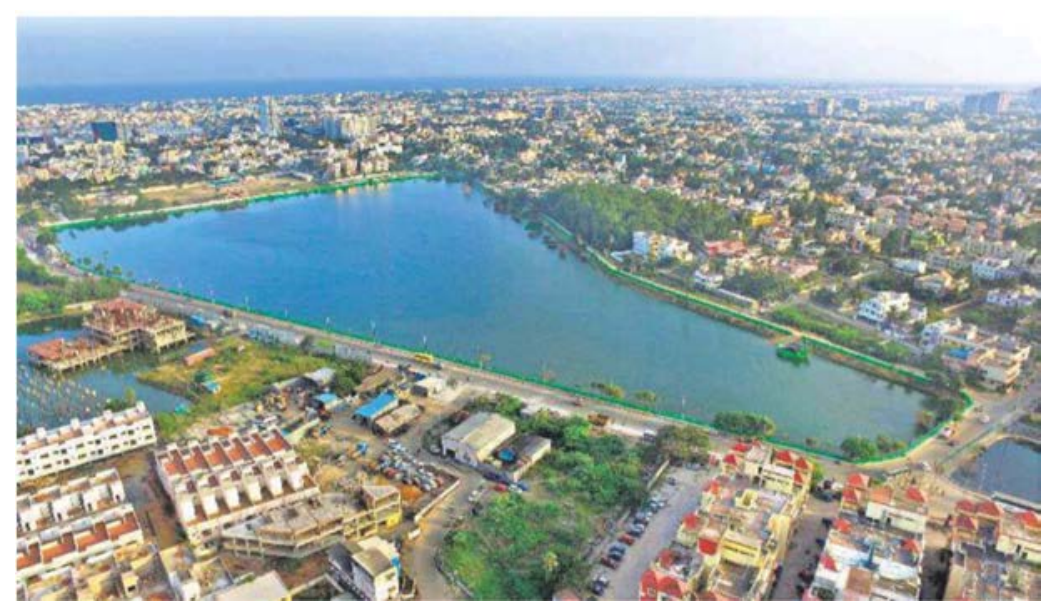

Figure 6: Perungudi lake in the midst of residential areas [7].

\subsection{Indicator 5: Proximity to public transport and good transport}

This analysis added to a growing body of evidence to ensure that people in both the districts doesn't seem to connect this indicator with green cities. Both the districts have very poor weighted average score of 2.03 and 1.63 respectively.

Existing Condition: In District $190 \%$ people are affluent and the biggest footprints are found in higher income areas where residents have larger homes and are more likely to have private automobiles. People in District 1 felt that owning a car is a status quo and taking a public transport should be used by low standard of people only. Few of the residents in District 1 responded stating that "reduction in carbon footprint" relates to environmental performance but they were less clear about its specific focus on green cities.

In District 2 people complaint about lack of public transport facilities and respondents on average slightly felt they could make a difference through their own behaviour, and they were sceptical about the extent their personal efforts actually contribute to mitigating climate change which leads to green cities. The percentages of bikes are more in this zone.

\subsection{Indicator 6 and 8: Decrease in the number of flora and fauna and reducing waste + zero waste to landfills}

With the very poor weighted average score the author demonstrates that the people from District 1 were unable to relate to the places in which they live and to broader ecological processes that are essential for life. Majority of them do not care on the final disposal of the waste in Pallikaranai marshland. But they complaint that Perungudi dump yard is causing lots of environmental problems such as ground water contamination, foul smell, odour etc. Interestingly, about $2 \%$ of the respondents have the willingness and knowledge to reduce, recycle and reuse.

In 1906, the Pallikaranai marshland was spread over 8000 hectares but as per today's scenario it has dwindled to smaller patches of foliage in southern Chennai amidst highways and IT parks [8]. Being a multifaceted ecological landscape this marshland was a refuge to a variety of 163 local and migratory birds and endangered species are now threatened by encroachments. The leachate oozing out from the dumpsite pollutes the 
ground water. Perungudi lake which is about 57 acres is being encroached by illegal temples and considerably reduced in size due to sand mining which eventually increased its depth.

In district 2 people themselves are in the constant threat of eviction and feel that the government is not at all concerned with the life of a human being and blamed about negligence of the authorities who have compromised the conservation of natural habitat of the migratory birds in their attempt to take up the developmental activities.

\subsection{Indicators 7 and 9: Reduction in surface run off and reduced air temperature}

With the weighted average score of approximately 3.5 for both the indicators it is very clear that $50 \%$ of the respondents are not aware of the replenishment of ground water through infiltration is important for maintaining a base flow in streams.

Existing Conditions: Majority of the Individual Plots in District 1 are completely paved with built structure which supports less infiltration.

\subsection{Indicator 10: Setbacks in buildings}

With the poor weighted average score from District 1 and District 2 the author concludes that people think setbacks as regulatory whims and feel that setbacks are bad economically as they force us to consume more land and they are not able to relate it to the green city indicators.

Existing condition: During our observation it was found in District 1 that $58 \%$ of the house has excessive Ground coverage without leaving mandatory setbacks. At the plot level they have the set back of 1-2 feet instead of 5 feet had been left on all four sides. $60 \%$ of the people in District 1 think that side set back on one side is sufficient for light and ventilation and they would like to build on the other side in violation to the side set back requirement. About $42 \%$ of the setbacks in emerging apartment buildings are mostly paved and people have misconceptions like all trees will cause structural damage to the buildings.

People in district 2 have permeable surfaces as they are in the verge of eviction and the houses in this zone are haphazard, inorganically developed and no space for green covers as it is overcrowded.

\section{CONCLUSIONS}

From the above study it is very clear that the local government of Chennai should take immediate action to stop the slow death of Perungudi and the nearby marshland and analysis clearly indicates that there are actually two kinds of victims - the people and the place. Both local people and the Pallikaranai Marsh are suffering equally from garbage dumping at the Perungudi site, posing a serious environmental threat to air and water and measures to be taken to protect the winged visitors and should develop as a bird watchers paradise in the near future.

In addition from the survey analysis one can conclude that other than green vegetation and green covers respondents cannot able to relate other indicators leading to the green city development. Moreover the Chennai city is missing separate department, lack of co-ordination among the forestry department, Chennai corporation and highway department to monitor the green-cover improvement activities. Above all, individual in the community should be educated and should have awareness regarding the indigenous plants, species selection and maintenance. 


\section{ACKNOWLEDGEMENTS}

My special thanks go to the two Assistant Architects Ar. G. Yogesh and Ar. K Ravindran who helped me conduct the survey at Perungudi.

\section{REFERENCES}

[1] Razia, S., Residents perception of green spaces for urban sustainability: A case study in Dhaka City. Master of Development Studies program, BRAC University, p. 9, 1989.

[2] Ministry of Housing and Urban Affairs, URDPFI Guidelines, Vol. 1 \& 2. http://mohua.gov.in/link/urdpfi-guidelines.php. Accessed on: 26 Jun. 2019.

[3] Ministry of Housing and Urban Affairs, URDPFI Guidelines, Vol. 1 \& 2. http://mohua.gov.in/link/urdpfi-guidelines.php. Accessed on: 26 Jun. 2019.

[4] Office of the Registrar General and Census Commissioner, India. http://censusindia.gov.in/2011-Common/CensusData2011.html. Accessed on: 26 Jun. 2019.

[5] Yogesh. G. \& Sharmila, J., Personal collection of Perungudi Map, 2018.

[6] Ravindran. K. \& Sharmila, J., Personal collection of Perungudi Park Plans, 2018.

[7] Rajendra, R., Water brought back to life. The Hindu. www.pressreader.com/. Accessed on 1 Jul. 2019.

[8] Preetika, B., Map of the week, Perungudi dumpyard. https://hashtagurbanismblog.wordpress.com/2017/07/21/map-of-the-week-perungudidumpyard/. Accessed on 1 Jul. 2019. 